\title{
Escutas da imagem: as resultantes do som nos componentes semióticos da linguagem visual
}

\author{
Autor: Wander Lourenço da Silva \\ Orientador: Prof. Dr. Miguel Luiz Contani
}

Resumo: Este trabalho analisa os efeitos comunicacionais e estéticos produzidos na relação entre os elementos imagéticos e sonoros dos filmes Vermelho Como o Céu, de Cristiano Bortone, e Laranja Mecânica, de Stanley Kubrick. A fundamentação teórica provém das categorias de sons e dos modos de escuta contemplados na Teoria Cinematográfica de Produção Sonora (FilmSound) proposta por Michel Chion e são relacionados às bases semióticas de C.S. Peirce. Utiliza também o conceito de imagem endógena de Hans Belting, as contribuições de Vilém Flusser acerca da construção das imagens mentais, e os conceitos das categorias estéticas tratadas por Sánches Vázquez e Umberto Eco. Analisando algumas sequências segundo as escutas reduzida, causal e semântica, pode-se afirmar que o som agrega à cena elementos importantes que contribuem para o resultado final, seja este de valor comunicacional ou estético. Conclui-se, em Vermelho Como o Céu, que o código sonoro contribui efetivamente para o realce das relações sinestésicas do filme além de funcionar como elemento gerador de sentindo na narrativa, pois é posto como principal elemento na construção imagética mental nos momentos em que o enredo aborda o comprometimento do sentido da visão. Em Laranja Mecânica, o som é componente responsável pela geração da ambiguidade presente na maior parte do filme, sobretudo nos momentos de aplicação da violência civil e de sistema. Pode-se afirmar que, nesse filme, a seleção musical cumpriu a finalidade de, ao agregar à cena elementos estéticos contrastantes aos imagéticos, produzir uma sensação de realce do grotesco pela mistura de prazer e horror e, por vezes, pela presença do cômico.

Palavras-chave: Imagem. Semiótica Visual e Sonora. Sinestesia. Estética. Comunicação. Música. Cinema. 


\title{
Listenings of the image: the resultants of sound in the semiotic components of the visual language
}

\begin{abstract}
This study analyzes the communicational and aesthetic effects produced in the relationship between the image and sound elements of the films Rosso come ilcielo by Cristiano Bortone, and A Clockwork Orange by Stanley Kubrick. The theoretical framework comes from thesound and listening modes included in Theory of Film Sound Production proposed by Michel Chion and they are related to semiotic bases of C.S. Peirce. Also used is Hans Belting's concept of endogenous images, the contributions of Vilém Flusser about the construction of mental images, and concepts of aesthetic categories treated by Umberto Eco and Sánches Vazquez. Analyzing some sequences according to the wiretaps reduced, causal, and semantics, we can say that the sound adds important elements to the scene that contribute to the final result, of communicational or aesthetic value. It is concluded, in Rosso come ilcielo, the sonorous code effectively contributes to the enhancement of synesthetic relations of the film, besides acting as an element that generates sense in the narrative as it is put as the main element in building of the mental imagery at times that the plot deals with the impairment of the sense of sight. In A Clockwork Orange, it is concluded that the sonorous component is responsible for generating of the ambiguity present in most of the film, especially in times of application of civil and system violence. It can be said that in this film, music selection was instrumental in adding to the scene elements in contrast to the imagery, thus producing a sense of the grotesque, enhanced by the mixture of pleasure and horror and sometimes by the presence of the comic.
\end{abstract}

Keywords: Image. Visual and Sound Semiotics. Synesthesia. Aesthetics. Communication. Music. Cinema.

Dissertação completa disponível em: http://www.uel.br/pos/ mestradocomunicacao/wp-content/uploads/Disserta\%C3\%A7\%C3\%A3oWander-Louren\%C3\%A7o.pdf 